\title{
Merits testing in the English legal aid system: exploring its impact in asylum cases
}

\author{
Tamara Butter
}

\section{Introduction}

There has been much discussion in recent years on the legal aid cuts and reforms in England and Wales and the possible consequences this would have on access to justice for vulnerable groups in society, including immigrants and asylum seekers. ${ }^{1}$ Many aspects of the English legal aid system are worthy of an empirically based examination in the light of asylum seekers' access to justice and several such studies have been done, particularly on the impact of funding cuts on the work of legal aid providers. ${ }^{2}$ In this contribution, I will focus on one element of the English legal aid system: merits testing by legal aid providers in asylum cases.

After the 2013 reforms, the English legal aid system continued to provide for legal aid in asylum cases to asylum seekers who are eligible. ${ }^{3}$ Eligibility is subject to a means test (insufficient financial means) and a merits test (prospect of a case being successful). This assessment is initially carried out by the legal aid provider who decides whether he can assist the client on legal aid. This assessment thus constitutes a crucial part in obtaining legal aid which, when it is not granted, can negatively affect asylum seekers' possibilities of obtaining access to justice. In addition, it is interesting to look at this particular element in view of the recent introduction in the Netherlands of the 'High Trust' scheme in which also a shift is made from the initial determination of eligibility by the Legal Aid Board to the legal aid provider, randomly checked afterwards by the Board. ${ }^{4}$

1 E.g. Sanderson \& Sommerlad 2011; Byrom 2013; Webber 2012a \& b; Meyler \& Woodhouse 2013.

2 Concerns include fixed fee payment and funding cuts; 'at-risk' phases for onward appeals (payment only if permission to appeal is granted); removal of most non-asylum immigration cases from the scope of legal aid; limits on the number of matter starts firms are granted (i.e. legal aid cases they can take on). The fear is that the combination of the last two measures leads firms to withdraw from the sector leading to a shortage of providers (Davidson 2013). Studies on impact of funding cuts, e.g. James \& Killick 2012; Gibbs \& Hughes-Roberts 2012.

3 Schedule 1, Part 1, para 30 Legal Aid, Sentencing and Punishment of Offenders Act 2012. After entering into force in April 2013, most immigration cases other than detention and asylum cases are 'out of scope'. See for an overview of the services in scope of legal aid: Meyler \& Woodhouse 2013, p. 58.

4 http://www.rvr.org/binaries/content/assets/rvrorg/nieuws/brochure-high-trust---nieuwewerkwijze.pdf. In general, the application of the merits test in the Netherlands in asylum cases is somewhat different. The test is less stern ('without any merit' Article 12(2)(a) Legal Aid Act; Article 3 Decree on the Criteria for Granting Legal Aid) than in England (see Section 4) and in asylum cases not strictly applied by the Legal Aid Board. See Butter 2014 on legal aid in the Dutch asylum process. 
The aim of this contribution is to explore whether and, if so, how merits testing by legal aid providers may affect the access to justice for asylum seekers lacking the financial means to pay privately for legal assistance and representation. To that end, the following questions will be discussed: How do legal aid providers go about applying the merits test? Does this affect asylum seekers' access to legal aid? May merits testing by providers affect the access to justice for asylum seekers?

This contribution is based on a qualitative interview study conducted in the context of a research project into the professional decision making of asylum legal aid lawyers. ${ }^{5}$ The sample consists of 22 solicitors based in different parts of England and with various backgrounds in respect of firm size, experience, membership of a specialized asylum association and gender. These data provide for an indication how the merits test is applied by a particular group of legal aid providers, i.e. Solicitors.

\section{Access to justice for asylum seekers}

\subsection{Asylum seekers as justice seekers}

Asylum seekers are persons who have crossed an international frontier into a country in which they apply for international protection. The justice asylum applicants seek in Europe is international protection based on either the Refugee Convention, the European Convention on Human Rights or the EU directives concerning asylum. ${ }^{6}$ The rights asylum seekers derive from these conventions can only be invoked once they are, in the case of Europe, on European territory, which thus constitutes a first hurdle to be overcome. In the asylum procedure in the receiving country, it is determined whether someone is eligible for protection and will be qualified as what is generally called a 'refugee'. In England, the Home Office is responsible for processing asylum applications. The determination procedure consists of a screening interview and a substantive interview based on which the Home Office takes a decision that is subject to appeal.

\subsection{Legal aid as a condition for access to justice}

Access to justice is defined in this special issue by the editors as comprising three elements: (1) the possibility to realize one's rights; (2) equal access to the law; and (3) the possibility to achieve justice outside the existing body of law. Below I seek to set out why legal aid is key in securing these three elements and thus a condition for ensuring access to justice for asylum seekers.

To realize one's rights (the first element) as an asylum seeker access to legal assistance and representation is vital for the following reasons. First, asylum seekers are in a country in which they are unfamiliar with the legal system and the asylum process and of which they often not speak the language. Moreover, they may

5 It is based on part of the research conducted for my $\mathrm{PhD}$ project, which concerns a comparative case study of the Netherlands and England on this topic. Fieldwork in England has been conducted in September 2012 and September to November 2014. 
arrive traumatized or with medical problems. Generally, they are considered vulnerable. Second, asylum law is subject to frequent legal and policy changes and developments in the world. Asylum procedures are legally complex and to ensure that all aspects of the asylum seeker's case are properly taken into account by the determining authorities, legal advice and assistance has become almost indispensable. ${ }^{7}$ Third, the asylum process is typified by an inequality of the parties involved, i.e. the state being a 'repeat player' versus the asylum seeker as a 'oneshotter'. ${ }^{8}$ The state's immigration authority routinely processes and litigates about asylum applications, whereas the interviews and possible subsequent appeals are one-off events for asylum seekers. Repeat players have strategic advantages in the procedure in several ways. ${ }^{9}$ Kritzer argues that the government's advantage has two key components that go beyond the usual elements associated with repeat players: firstly, the government makes the rules by which we all play; secondly, in the end, it are government officials who make the decisions. Ultimately judges are, despite their formal independence, part of the regime, and 'when the regime comes under challenge, the government will tend to receive any breaks or benefits at the margin that might accrue'. ${ }^{10}$ This might especially be the case in the area of immigration and asylum law which is politically sensitive. ${ }^{11}$ As regards the rules, the government makes the rules governing the entry of asylum seekers, and it can tighten its procedural aspects, which it has done in the UK. ${ }^{12}$ Introducing a lawyer (being a repeat player) constitutes one attempt to help compensate for the apparent inequality between the parties. ${ }^{13}$

These arguments also apply to the second element: Equal access to the law irrespective of personal status, power, knowledge, or income. The latter requires that legal aid is available for those asylum seekers who, because of a lack of financial means, cannot afford the legal assistance and representation required to (albeit partly) compensate for the differences in personal status, power, and knowledge. Regarding the third element - the possibility to achieve justice outside the existing body of law when the existing body of law is considered to be unsatisfactory in achieving justice - legal assistance and representation (through legal aid) can also be of great importance; it might even be a precondition. In order to achieve access to justice in this sense of the term, a certain type of legal assistance is required. It requires what Schuyt et al. call 'law shaping legal assistance' or even

8 Galanter 1974.

9 E.g. expertise, ready access to specialists, the possibility to develop facilitative informal relations with institutions, and to adopt strategies to maximize gain in the long term. Since the stakes in one particular case may be not that high, they can afford to play for the rules. For asylum seekers, the stakes are high: it can be a matter of life or death.

10 Kritzer 2003, p. 362.

11 Cf. Spijkerboer 2014.

12 E.g. Webber 2012.

13 This is clearly only one element influencing possible equalization. The others are institutional facilities, rules, and organization of the parties (Galanter 1974, p. 125 - Figure 3). 
'law reforming legal assistance'. ${ }^{14}$ Especially in the area of asylum law, with its above-mentioned particular features, this type of legal aid can be considered indispensable for asylum seekers lacking the legal skills and expertise required for shaping or reforming the law.

Having a legal aid system in place which provides for legal aid for asylum seekers is thus an important - yet not sufficient - condition for their access to justice, in the broadest sense of the term. However, not merely having such a system, but the way it functions in practice determines whether legal aid can contribute to asylum seekers' access to justice.

\section{The English legal aid system and merits testing ${ }^{15}$}

The Legal Aid Agency (hereafter: LAA) is the executive agency of the Ministry of Justice that administers legal aid services in England and Wales. It commissions and procures legal aid services from providers. Not only solicitors but also registered immigration advisers and legal executives - and those working for and under the supervision of one of these three - can provide legal aid work in asylum procedures if the organization they work at holds a contract with the LAA. The 2013 Standard Civil Contract regulates the terms, conditions, and funding of legal aid work in asylum cases. ${ }^{16}$ The table below shows the different funding stages.

\begin{tabular}{lll}
\hline Funding & Level of Service & Stage of Asylum Application \\
\hline Controlled work & Legal help & $\begin{array}{l}\text { First instance, i.e. application to } \\
\text { Home Office }\end{array}$ \\
$\begin{array}{l}\text { Controlled legal represen- } \\
\text { tation }\end{array}$ & $\begin{array}{l}\text { Appeal before the first-tier and } \\
\text { upper tribunal (immigration and } \\
\text { asylum chamber) } \\
\text { Onward appeal to the Higher Courts } \\
\text { and judicial review }\end{array}$ \\
\hline
\end{tabular}

When a client comes to a solicitor for legal help, as a provider he must check (1) whether the case is one for which legal aid is available (scope); (2) the client's financial eligibility (means); and (3) the prospect of the case being successful (merits). The merits test needs to be applied continuously throughout the asylum process. To obtain legal help the client needs to meet a 'sufficient benefit test'. ${ }^{17}$

14 Schuyt et al. 1976, p. 63. The authors distinguish five types. The first three are preventive-, diagnostic-, and dispute-regulating legal assistance. Law shaping legal assistance entails inciting case law through offering legal representation in court cases in which vague, unclear, or weak rights are being transformed into more specific or stronger rights. Law reforming legal assistance entails advancing changes in existing legal positions, either via the courts or via the legislator; it involves trying to obtain legal protection for new (social) needs.

15 This description is based on the legislation applicable at the time of completion of the fieldwork (November 2014). In the meantime, the merits test has been adjusted (see note 18).

16 https://www.gov.uk/government/publications/standard-civil-contract-2013.

17 Section 32 Civil Legal Aid (Merits Criteria) Regulations 2013. 
Eligibility for Controlled Legal Representation and for Licensed Work is subject to a more demanding merits test; there must in principle be at least $50 \%$ prospect of success. ${ }^{18}$

The powers to determine eligibility for Controlled Work are delegated to the provider; he must thus carry out the means and merits assessments and decide whether he may assist the client on legal aid. Providers have to fill in a form on which they explain why the tests are met. For the merits test, this involves a stepby-step guide for explaining the merits and includes questions such as 'What are the prospects of this appeal being successful?' 'Give brief reasons with reference to your client's case', and 'Do the likely benefits to be gained from the proceedings justify the likely costs?'19 This assessment may be checked afterwards by the LAA during audits. If the provider refuses funding on appeal because he considers that the merits test of $50 \%$ chance of success is not met, the client can appeal that decision with the LAA. The provider must inform the client about this right to a review. ${ }^{20}$

Powers to determine eligibility for Licensed Work are not delegated to the provider, but remain with the LAA. ${ }^{21}$ This contribution will focus on merits testing at first instance (application with the Home Office) and on appeal before the firsttier tribunal, where the powers to determine eligibility are delegated to provider. How do solicitors providing legal aid view the merits test and how do they apply it?

\section{Application of the merits test by solicitors}

Whereas some respondents say they have no problem applying the merits test because they feel they can rely on their experience, most do find it difficult. As this solicitor explains:

18 Section 60 (3) Civil Legal Aid (Merits Criteria) Regulations 2013 (as amended by amendment 2014 No. 131) reads:

The Director must be satisfied; the prospects of success are:

a very good, good or moderate; or

b unclear, and

i the case is of significant wider public interest;

ii the case is one with overwhelming importance to the individual; or

iii the substance of the case relates to a breach of Convention rights.

Para 4.1.4 Lord Chancellor's Guidance under Section 4 of LASPO 2012 (June 2014) reads: "If the prospects can be identified as below $50 \%$, or are considered borderline, any application that is subject to a prospects of success must be refused".

NB: On 27 July 2015, an amendment to the merits regulations came into force entailing that legal aid may be provided for some of the cases that are assessed as having 'borderline' or 'poor' changes of success (Civil Legal Aid (Merits Criteria) (Amendment) (No. 2) Regulations 2015).

19 https://www.gov.uk/government/uploads/system/uploads/attachment_data/file/346246/legalaid-controlled-work-2-immigration.pdf.

20 Para $8.41 \mathrm{ff} 2013$ Standard Civil Contract (version 1 April 2013).

21 The LAA checks the application of the means and merits test by the provider and issues a certificate if it agrees that funding should be granted. 
[...] to assess the merits I find quite tricky at times to be honest. Because there's a lot of material to consider and I don't like refusing funding for what could have been a genuine case. You've placed somebody at risk and not given them the full opportunity to present their case. I find that very, very difficult. $^{22}$

Virtually all respondents explicitly refer to the responsibility they feel when applying the merits test, because they are dealing with public funds: They have 'custody over public money', are looking after 'the public purse', and must thus be careful when spending 'taxpayers' money'. Yet, while taking that into account, there is a difference in how they actually apply the merits test. Given the different tests that apply at first instance and on appeal, I will discuss these stages separately.

\subsection{Merits testing in first instance}

The moment at which a client first approaches the legal aid provider differs. This can be before applying for asylum or after having applied and being matched with the provider after the screening interview. ${ }^{23}$ When the provider first meets, the client can play a role in how the provider approaches the merits test. For many respondents the mere fact that someone has claimed asylum is enough reason to grant legal aid; the sufficient benefit test is met. One respondent, who normally takes on clients after the screening interview, has quite a clear stance on this:

We don't look at the merits of their case at that stage. [...] If someone has a hopeless case, they're still entitled to the advice to assess their case and tell them their case is hopeless.[...] So there's always sufficient benefit to take an asylum case on and advise them about the process and the merits of their case and deal with it up until the decision of the Home Office. ${ }^{24}$

For some this is somewhat different when the potential client has not yet applied for asylum, and when it is obvious to the solicitor, there are no asylum grounds. ${ }^{25}$ Others interpret the sufficient benefit test more strictly and are of the view that - even after registration of the asylum claim - they still have to make their own assessment: "We don't take cases solely on the basis that the Home Office has accepted their claims at the screening interview. We go slightly beyond that point". ${ }^{26}$ Some decide this on the basis of the applicant being a 'genuine' asylum seeker (see below), whereas others consider this less relevant and focus rather on

eng11-s-3-y-f.

There is a Voluntary Appointment System to facilitate setting up appointments. Providers can request to participate in the system in case it operates in the procurement area of the firm. The Home Office and two not-for-profit organisations can access this system to find a lawyer nearest to where the applicant is located and arrange an appointment.

eng14-med+10-y-m.

E.g. 'A South-Korean man said, "I'm being persecuted, because I'm gay in South-Korea". I said, "I can't do your case, at all. There's no persecution"' (eng6-s-3-10-y-m).

eng17-med-3-10-y-m. 
their opinion about the chances of the claim being successful. One interesting example in this regard is the case of a Libyan applicant who stayed in the UK as a student and subsequently applied for asylum. He claimed that he would be at risk of going back, because his family was associated with the Gaddafi-regime. The respondent assisting him accepted that this is in principle a valid claim but decided not to further assist the applicant at the initial stage. It turned out that the client had been back to Libya 6 months ago and came back with no harm, which the solicitor states 'completely destroys any claim' as it shows that there is no risk upon return. ${ }^{27}$ In support of his decision not to further assist this client on legal aid, he points to the risk one would run at audits when being too lenient. ${ }^{28}$ The other respondents who are strict on the merits test at this stage also refer to the need to justify towards the LAA why they granted legal aid and that it may be detrimental to the legal aid contract if they fail to do so.

\subsection{Merits testing on appeal}

For most respondents, however, the merits test actually becomes an issue only after a refusal. At that point the test is no longer whether there is a sufficient benefit to the individual, but whether the case has at least $50 \%$ prospect of success. Several respondents adopt what can be considered a 'liberal' approach to the merits test. Generally, as long as they feel they can bring something substantial forward, they are likely to proceed. They feel very confident about their own judgement and say they never had any issues with the LAA; if they would be asked about their motivations for proceeding, they would be able to justify it.

Others interpret their role as 'gatekeepers' more strictly and are more ready to live up to the expectations in this regard. Either because they feel it is the right thing to do or because they are concerned about their relation with the LAA. The fear of not getting paid or losing the contract when being too lenient in granting funding seems to play a key role:

We're very careful. When the LAA calls for the files for peer review then they always assess and ask questions 'why did you grant legal aid at this stage?' The legal aid money should be used for proper cases, for cases that have prospects. [...] We've been given devolved powers to assess merits, means and sufficient benefits. We should do it properly, otherwise the money won't be paid. ${ }^{29}$

28 This respondent believes that the criteria at first instance and appeal are the same (50\% chance of success). Even though this is actually not correct, it does show that his choices are guided by fear for LAA reprimands.

29 eng10-s-3-y-f. The LAA uses peer review to measure the quality of providers' work. Based on peer review ratings, the LAA can take measures which may affect the provider's contract (e.g. termination in case of confirmed low ratings: www.gov.uk/government/uploads/system/uploads/ attachment_data/file/314274/independent-peer-review-process.pdf Section 7.15 ff. 


\subsection{Credibility}

Allowance of asylum claims often hinges upon the credibility of the applicant's account. If this is found incredible by the Home Office, two ways of dealing with the merits test can be distinguished among the respondents. Those adopting a liberal approach are, generally, of the view that credibility is for the judge to decide. The judge has the freedom to form his own opinion about the facts of the case and a successful appeal very much depends on the judge. Virtually all respondents acknowledge that the person of the judge plays a very important role, but how this is weighed differs. Illustrative for the respondents who do give much weight to this element is the example a solicitor gives of what she describes as a very weak case. The client has given three completely different accounts of what happened; there were lots of problems and discrepancies and the Home Office argued that this account was completely unreliable. Yet the case was pursued and won on appeal. This respondent is thus very reluctant in meriting such cases out since "it's difficult to say no when you know that weak cases can win with the right judge on the right day". ${ }^{30}$

The second approach to assessing the merits in cases concerning credibility issues is to give less weight to this element. A respondent who does acknowledge the critical role played by the judge explains, however, that "you don't base your merits decision on what judge you are going to get. Because you expect fairness in a tribunal anyway. So you just proceed with what you feel the merits are". ${ }^{31}$ Like this solicitor, several other respondents also base their decision on their own assessment, taking the uncertainties inherent in the system (i.e. the unpredictability of the judge) not so much into account when assessing the merits. One respondent places much emphasis in his assessment on whether he considers the client to be 'genuine'. He refers to a case of a heavily traumatized woman in which, even though the Home Office provided compelling reasons for the refusal, he could 'actually tell this client is being sincere and genuine'; therefore, "you end up granting legal aid for those cases once you are convinced these things happened to this client". ${ }^{32}$ Other respondents place less emphasis on their own convictions, but more on whether one believes that the case could stand up in court. Unlike the respondents who believe that credibility is for the judge to decide, they are less likely to give the client the benefit of the doubt in cases concerning credibility issues when to their mind the merits have dropped below $50 \% .{ }^{33}$ Illustrative are the examples of two respondents who were reprimanded by the LAA for refusing legal aid following a client's application for review of the refusal. In both cases, the LAA found that the provider should have given the client the benefit of the doubt. One example concerned the case of an Iranian man who claimed to be a journalist, about which the solicitor states "the information he was giving about his knowledge about the media in Iran was so bad, how could the guy really be a

30 eng7-med-+10-y-f.

31 eng11-s-3-y-f.

32 eng17-med-3-10-y-m.

33 This does not mean that they do not try to find arguments and assist the client in collecting corroborating evidence (e.g. expert reports); many of these respondents stress that they do make an effort to reach the $50 \%$. 
journalist? And his claim was so inconsistent with lots of mistakes". ${ }^{34}$ The evidence (newspaper articles) the client did provide would, according to the respondent, not override the lack of information provided earlier. Even though it seems the respondent himself does not believe the client, he says he is not pursuing the case because he deems a judge would not accept the account. The other example concerned the case of a young woman who claimed she fled from the DRC for fear of female genital mutilation. The respondent explains "It was a credibility issue and based on the evidence I could not do it. Based on my previous experiences this was not 50\%". He refers to how the application of the legal test in these cases works and how the available evidence would not stand in court. In response to my question what stops him from pursuing these kind of cases, he explains:

If you go on that route then there's no point in merits testing at all. We're bound by it to use our professional opinion and experience to apply it. We are using taxpayers money. Our role is to some extent the same as the judge. The same things apply. On the available evidence you have to make the best decision you can. ${ }^{35}$

Clearly it all depends on the particular circumstances of a case and these solicitors might have been right about how it would have gone in court. However, the fact that they adopt this legalistic approach and are less willing to give clients the benefit of the doubt in such cases, does hamper asylum seekers' access to court with the assistance of a legal representative.

One other example which shows how a provider, who strongly feels he needs to act as a gatekeeper in order not to 'get in trouble', applies the merits test and how this may work out.

When you're a legal aid provider sometimes you have to, when you think a case is so poor, stop representation. There've been one or two occasions where I've subsequently been aware that my client had gone to the court and got asylum. [...] So nobody is perfect. But sometimes ... there are all sorts of variables on that, some judges will just allow any case. ${ }^{36}$

Regardless of providers' motivation, we see a crucial difference in the application of the merits test amongst solicitors, which clearly has consequences for asylum seekers' access to legal aid and ultimately possibly for their access to justice. There are solicitors who tend to give their client the benefit of the doubt in cases concerning credibility issues, because they accept that it is for the judge and not for them to decide on credibility and because they recognize that the chances of winning a case heavily depend on the judge who will hear the case. Conversely, there are solicitors who are less willing to take that into account. The motivation for this stricter approach seems to lie either in one's belief that it is the provider's 
responsibility to use funding for 'proper' cases or in the fear of damaging the relation with the LAA and the implications that might have for the solicitor's business, even though this particular fear may be unfounded - those adopting a liberal approach report they never had any issues with the LAA about their merits assessments. ${ }^{37}$ Whatever the underlying motivation, the accounts discussed above show that these providers appear to see themselves to some extent as judges or, even if they do not see themselves that way, they do act judge-like. The fact that they are instructed to assess the prospect of a case beforehand to such an extent that there must be $50 \%$ chance of success, encourages this attitude and subsequent conduct: it incites judging the client instead of solely representing them.

One respondent who is very aware of the risk of acting too judge-like - which he sees happening around him - explains he constantly tries to correct himself because "if I must be really harsh on myself, you can get caught up with stereotypes [...] And into thinking, these sort of claims are commonplace". ${ }^{38}$ He mentions two recent cases in which he almost decided not to proceed, because he could not imagine the situation as portrayed by the client could have actually happened; both cases were allowed by the judge. This again shows the possible consequences judging instead of representing a client.

\subsection{Legal aid vs. private clients: different duties?}

If a solicitor feels that that he cannot justify granting legal aid because of the poor chances of success, alternatives for helping the client outside the legal aid scheme were brought forward. First, informing the client about lodging the appeal by himself. The solicitor will not assist the client in court. Second, exceptionally provide certain services pro bono. Third, in case the client nevertheless manages to collect money from family or friends, offering services on a private basis. Since "if people are paying me privately, I can do whatever they want, obviously. I'm a solicitor with a reason" as long as "my ethics are not breached". ${ }^{39}$ As another respondent put it "I will run something that I think will have a slim chance of success privately". ${ }^{40}$ Several respondents point to the differences in their role as a solicitor in public as opposed to private cases. One solicitor, even though he considers himself 'liberal' on the merits test, refuses people legal aid when he thinks the chances of success are very small, but is willing to continue on a private basis:

R: [...] Some people will pay if they think the chances of success are only $10-20 \%$.

I: So there's really a difference? With a paying client you would and with a non-paying client you wouldn't?

37 Yet, many respondents mention other funding conflicts with the LAA (e.g. withdrawal because of incorrect application of the means test) which might explain the cautious attitude of some.

38 eng15-med-3-y-m.

39 eng4-1-+10-y-f.

40 eng13-s-+10-y-m. 
R: Yes, I think professionally we're obliged to. You can't put forward spurious arguments to a court, but if they're fairly weak; you're allowed to put forward weak arguments. If a client instructs you to do it and as long as you've advised them about the prospects of success and the likely consequences, I think as a solicitor you are obliged to do it. ${ }^{41}$

He does so because he believes that as a solicitor one is 'professionally obliged to act in your client's best interests'. Consequently, one can infer that, under legal aid scheme, he finds he cannot fulfil his professional duties, i.e. act in the client's interests by pursuing cases with less than $50 \%$ but still some chance of success.

\section{Conclusion}

The aim of this contribution was to explore the possible impact of merits testing by legal aid providers on asylum seekers' access to legal aid and, consequently, on their access to justice. First in regard to access to legal aid, we have seen that providers have different ways of dealing with the merits test both at first instance and on appeal. Asylum seekers' access to legal aid is not likely to be at risk when they manage to acquire one of those solicitors who (1) considers that having claimed asylum means that there is sufficient benefit to grant legal aid and provide assistance at the initial stage (even though the provider himself might consider the case hopeless) and (2) adopts a liberal approach to the merits test on appeal, i.e. is willing and dares to run arguments not yet pursued or pursued in an slightly different way and who leaves decisions about credibility to the judge. If applied in that way, the merits test does not seem to present much of a threat to access to legal aid. A risk, however, does seem to lie with those solicitors who tend to act judge-like and are inclined to substitute their own judgement about credibility for that of the judge. Interestingly, this attitude (or being more 'careful' when applying the merits test) appears to be more prevalent amongst solicitors working in the smaller or sole-practitioners' firms. This could be related to the risks associated with flawed merits assessments; they might not be in the position to absorb any possible adverse financial consequences. Solicitors working at larger or well-established firms might be less susceptible to this pressure because these firms would be able to absorb such costs. Moreover, solicitors' perceptions of how the LAA reviews providers' merits assessments differ. Even though the respondents adopting a liberal approach report they never had any issues with the LAA on this matter and the LAA may not easily criticize the provider's application of the merits test (nor attach consequences to it), the mere fact that the LAA could do so already appear to have an impact on some. ${ }^{42}$

May merits testing by providers, and the way in which it in certain circumstances restricts access to legal aid, affect asylum seekers' access to justice? We have seen

41 eng14-med+10-y-m.

42 Cf. Sommerlad, 2008, who points at contract compliance audits leading to a shift in practitioners' primary objective to meeting the requirements of the audit rather than serving the clients (p. 186). 
that there have been situations in which clients, after their solicitor refused legal aid based on the merits test, either went to court themselves and obtained asylum or appealed the refusal with the LAA, who corrected the provider's too strict application of the merits test. In the first scenario, asylum seekers' access to legal aid is adversely affected by (the provider's strict application of) the merits test, but these asylum seekers managed to obtain access to justice without being legally represented. Yet, going to court without a representative requires perseverance and certain skills which not all asylum seekers - especially the most vulnerable ones - may possess. So in case the merits test is applied too strictly, this clearly does present a risk to asylum seekers' access to justice. In the second scenario, the too-strict application of the merits test is corrected by the LAA. So one could argue that the system has safeguards in place to remedy this. But again, it does require an applicant who has the strength and capacity to question the decision of the solicitor. Those who do not may be adversely affected by the way in which the merits test is applied by some solicitors, which may ultimately limit their access to justice.

In this regard, equal access to the law regardless of income seems to be at stake. Because of the merits test, legal aid is usually not granted in cases in which the provider considers the prospect of success below $50 \%$ (e.g. 10-20\%). Clearly this is precisely the aim of the merits test, but it does mean that those lacking the financial means to pay privately cannot pursue cases with small chances of success with the assistance of a legal representative, whereas those who have can. ${ }^{43}$

Returning to the two dimensions of access to justice that can be distinguished, i.e. the ability to achieve justice within and outside the existing body of law, we see that merits testing by legal aid providers may affect both. If a solicitor is too strict on credibility, this might hamper the ability to achieve justice within the existing body of law. If a provider is reticent - because of the responsibility conferred upon him to determine the prospect of success - in pursuing the less straightforward cases (submitting less obvious, maybe far-reaching arguments) and is thus hesitant in providing 'law shaping' or 'law reforming' legal assistance on legal aid, this may have negative consequences for the possibilities to challenge the status quo and achieve justice outside the existing body of law. ${ }^{44}$ It may jeopardize the transformation of weak rights into stronger rights or the establishment of legal protection for new needs through litigation, which might especially in the area of asylum law be indispensable. In brief, having a legal aid system that makes legal aid on appeal conditional upon a case having at least $50 \%$ prospect of success and that makes legal aid providers responsible for conducting this assessment bears the risk that possibly restrictive government policies remain unchallenged and that access to justice for vulnerable groups, i.e. destitute asylum seekers, is not fully realized.

43 Unless a solicitor is willing and able to do pro bono work, which one cannot rely on.

44 Typically, the actual law shaping or reforming activity occurs at onward appeals. Yet, hesitance to proceed at the first appeal does not promise much for onward appeals, since at the upper tribunal stage, there is an additional obstacle: preparatory work is done at risk of not getting paid when permission to appeal is not granted. Para 8.93 ff. 2013 Standard Civil Contract (version 1 April 2013). 


\section{References}

Butter, T., 'Providing legal aid in asylum procedures in the Netherlands: A Challenging Business?' in: B. Hubeau \& A. Terlouw (ed.), Legal aid in the low countries, Antwerp: Intersentia 2014, p. 105-121.

Byrom, N., The State of the Sector: The Impact of Cuts to Civil Legal Aid on Practitioners and Their Clients, Coventry: Centre for Human Rights in Practice, University of Warwick 2013.

Davidson, E., "Economically unviable" firms respond to tender results 2013, http://www. legalvoice.org.uk/2013/01/10/good-and-bad-news-as-lsc-reveals-tender-results/

ECRE, The Way Forward: Towards fair and efficient asylum systems in Europe, Brussels: European Council on Refugees and Exiles 2005.

Galanter, M., 'Why the "Haves" come out ahead: Speculations on the limits of legal change', Law and Society Review, 1974-9(1), p. 95-160.

Gibbs, J., \& D. Hughes-Roberts, Justice at Risk: Quality and Value for Money in Asylum Legal Aid, London: Runnymede Trust 2012.

James, D., \& E. Killick, 'Empathy and expertise: Case workers and immigration/asylum applicants in London', Law \& Social Inquiry, 2012-37(2), p. 430-455.

Kritzer, H., 'The Government Gorilla. Why does government come out ahead in appellate courts?' in: H. Kritzer \& S. Silbey (ed.), In litigation: Do the 'Haves' still come out ahead? Stanford: Stanford University Press 2003, p. 342-370.

Meyler, F., \& S. Woodhouse, 'Changing the immigration rules and withdrawing the "currency" of legal aid: The impact of LASPO 2012 on migrants and their families', Journal of Social Welfare and Family Law, 2013-35(1), p. 55-78.

Sanderson, P., \& H. Sommerlad, 'Colonising law for the poor: Access to justice in the new regulatory state', in: V. Bryson, Redefining social justice: New labour, rhetoric and reality, Manchester: Manchester University Press 2011, p. 178-200.

Schuyt, C.J.M., C.A. Groenendijk, \& B. Sloot, De weg naar het recht, Deventer: Kluwer 1976. Sommerlad, H., 'Reflections on the reconfiguration of access to justice', International Journal of the Legal Profession, 2008-15(3), p. 179-193.

Spijkerboer, T., De Nederlandse rechter in het vreemdelingenrecht, Den Haag: Sdu 2014.

Webber, F., 'UK: The real “immigration debate”', Statewatch Journal, 2012a-22(2/3), p. 10.

Webber, F., Borderline Justice: The Fight for Refugee and Migrant Rights, London: Pluto Press 2012b. 